\title{
How Did the Lost Shangri-La Get Lost? The Tragedy of the Groundwater Commons in Lijiang, China
}

\author{
Yan Zhang ${ }^{1,2}$ (D) \\ 1 Centre of Development Studies, University of Cambridge, Cambridge CB3 9DT, UK; yz333@cam.ac.uk; \\ Tel.: +44-775-225-4972 \\ 2 School of Economics, Yunnan University, Kunming 650091, China
}

Received: 17 September 2020; Accepted: 5 November 2020; Published: 8 November 2020

\begin{abstract}
Groundwater is critical to human survival, however, it has constantly been overexploited around the world. Despite hydrological causes and the effects of global climate change, groundwater governance has an essential role to play in causing or preventing such overexploitation. This paper presented a case of groundwater governance in Lijiang, renowned for its natural beauty and exotic cultures, located in northwest Yunnan, China. Since being designated as a UNESCO World Heritage site in the 1990s, Lijiang has experienced dramatic tourism development, which eventually escalated its groundwater crisis. This paper applied the diagnostic approach of social-ecological systems to analyse the institutionalised governance process in the case of Lijiang and substantiated the effectiveness of the Social-Ecological Systems (SES) approach in explaining groundwater management issues. Two significant findings were drawn in the case of Lijiang. First, institutional arrangements may play an essential role in resource management, but their analysis is lacking between macro modelling of planetary boundaries of the Earth and micro surveys of individual and community behaviour. The SES framework offered a useful tool to fill this gap. Second, the designation of Lijiang's Outstanding Universal Values as a world heritage site ironically damaged its local cultural intimacy, which nurtured generations of collective action for Naxi people, escalating the tragedy of its groundwater commons.
\end{abstract}

Keywords: groundwater commons; social-ecological systems; institutionalised governance; outstanding universal values; China

\section{Introduction}

\subsection{Governing the Groundwater Commons}

Groundwater is an important part of water resources [1]. It is one of the key elements in maintaining a healthy ecological environment [2]. Groundwater plays an irreplaceable role in maintaining the vegetation, regulating the rivers' runoff, and conserving a sustainable ecological environment, in the process of its formation, conversion and relocation [3]. It is also the essential water reserve for emergency and drought. Another essential role of groundwater is its multiple years' regulatory function. When the surface water supply decreased dramatically because of drought or other unexpected events, groundwater could be supplied to maintain people's livelihoods. Groundwater is one of the most prominent factors in sensitive geological disasters [4]. It plays a crucial role in germination, development and formation of geological disasters. Therefore, groundwater is not only a useful natural resource but also an essential integral part of the environment. The dramatic changes in the environment, such as precipitation and river runoff, would also cause dramatic changes in groundwater capacity and quality, which then would lead to major environmental changes [5]. 
Studying groundwater governance, especially on the community level, as common-pool resources have become an important strand of research over recent years [6-10]. However, the dilemma is that not enough convincing evidence has been documented over a great number of empirical case studies, and there is a lack of systematic groundwater governance research compared to physical studies of groundwater hydrogeology [11]. There were two main explanations for this dilemma: the disconnection between community-based groundwater management and its nested larger policy-making system at other levels; and incompatibility of models analysing relevant social systems of groundwater management and ecological systems of the groundwater resource. The main objective of this paper was to analyse institutionalised governance process of groundwater management (first focus) under the social-ecological systems integration dynamics (second focus), using an empirically grounded case study of Lijiang, China.

Hardin's classic "Tragedy of the Commons" asserted that human beings are unable to obtain optimal cooperation on the commons due to its non-exclusive and highly competitive nature [12]. Since then, extensive research has been conducted on the issues of the commons, leading to long-term debates of governance approaches based on either external government's coercive force or thorough privatisation in the market [13]. However, together with substantial case studies of the commons, the possibility of independent management of common resources by the local community under certain institutional arrangements showed a "third way" to solve the tragedy of the commons [14,15]. These commons scholars have long been committed to empirical case studies and institutional design principles for achieving sustainable resource governance [16-19]. With the deepening of research, they further realised that the successful cases of self-governing commons obtained balanced coordination and interaction between social and ecological systems. In 2009, Ostrom proposed the so-called social-ecological systems (SES) analytical framework, providing a new theoretical perspective and analytical tool for people to analyse the governance of the commons [20,21]. Instead of prescribing panacea of tried-and-trusted institutional recipes of the state or the market, Ostrom argued that we need a flexible diagnostic approach with institutional diversity to match with the diversity of ecological systems. The problem of overexploitation of groundwater resources, for instance, can be regarded as a node on the broader social-ecological interaction chain. Only by fully understanding the complex interaction between social-ecological systems, we can understand various mechanisms of cooperation and conflict on the commons, and hence design adaptive management to deal with resource vulnerability and enhance resilience [22-25].

As shown in Figure 1, the social-ecological systems (SES) analysis is a multi-level framework. Based on Ostrom's general framework of conceptual level (first-tier of variables), it includes four main internal variables-resource system (RS), resource units (RU), governance system (GS), and user (U). The SES framework also includes the social, economic and political background as settings (S) and external related ecosystems (ECO) as two external variables. The four internal variables are nested within a larger context of two external variables. Interaction (I) does not only occur amongst internal variables but also with two external variables. Interactions eventually generate particular outcomes (O) in the SES systems [21]. Taking groundwater management as an example, a specific groundwater system, like in the case of Lijiang can be called as a resource system. The extractable groundwater resource is called resource units. The relevant government, non-governmental organisations and local management rules of the specific groundwater system is the governance system with various users engaged in extracting groundwater resources. Based on the further elaborated second-tier variables of SES systems, Ostrom provided a panoramic diagnostic approach with a general theoretical framework for resources management analysis. People can select relevant key variables from the SES framework to form specific theoretical hypotheses based on specific resource issues and scenarios, and further, construct tailor-made models to investigate interactions and outcomes amongst different variables [26]. 


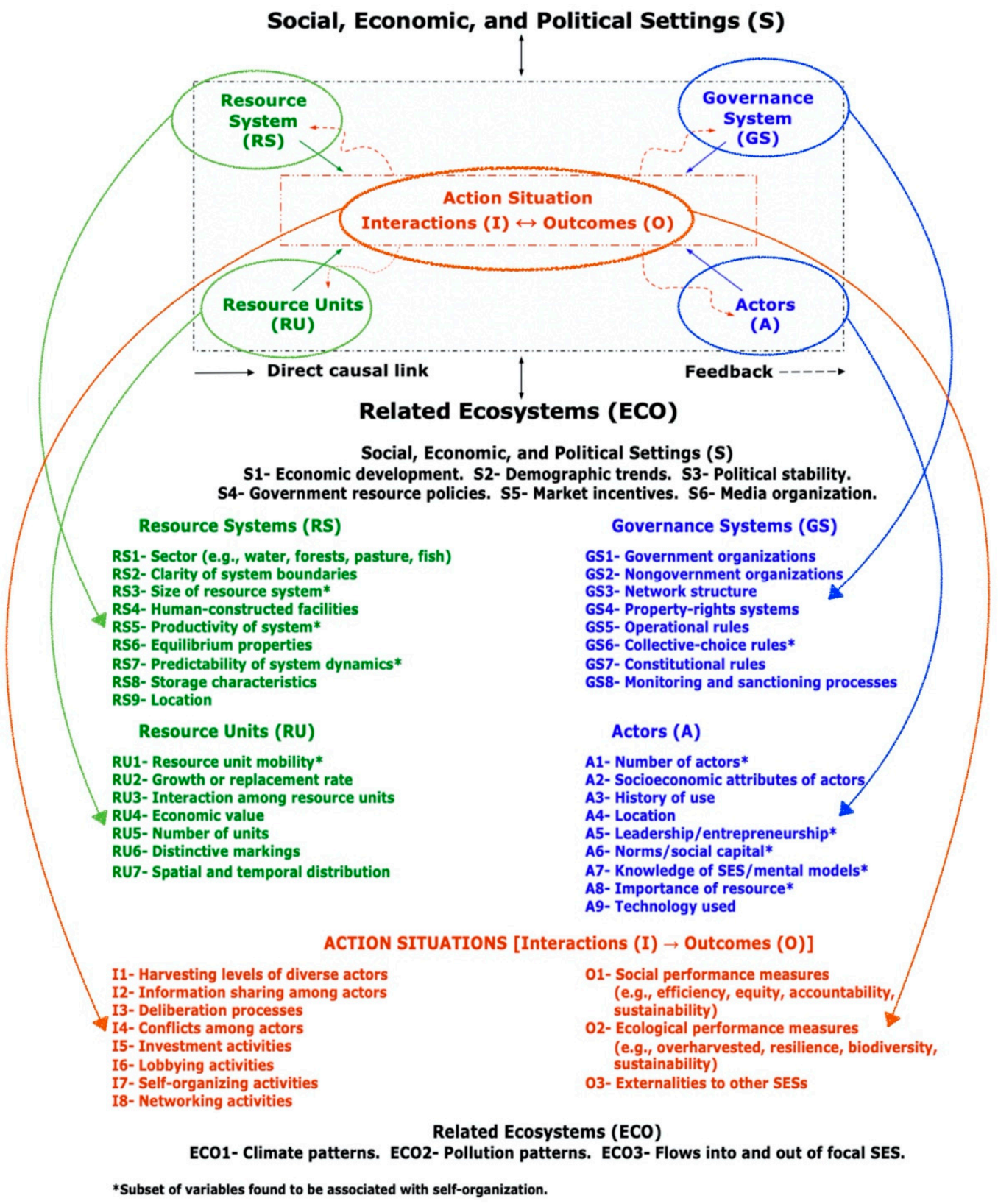

Figure 1. SES and second-tier variables, adapted from Ostrom $(2007,2009)[20,21]$.

\subsection{Material and Method}

This paper studied the empirical case of Lijiang groundwater management to put the important social scientific concept of the commons in question. It also sheds lights on an expanded integrated framework of the commons under the social-ecological systems framework [27]. This study was carried out in the field between December 2017 to February 2018. The study used qualitative methods, such as archival studies and in-depth interviews, which were mainly conducted in the city of Lijiang, as summarised in Figure 2. The research was conducted using secondary data, semi-structured and open interviews, as well as ethnographic and participant observations. Descriptive empirical materials can be well organised into a case study that explores the system of individuals and environments. In particular, the cultural intimacy of the Naxi heritage in Lijiang could be better captured through informal interviews defining direct lived experience of local communities. As Bromley defined, a case study is "a systematic inquiry into an event or a set of related events which aims to describe and explain the phenomenon of interest" (p. 302) [28], that "emphasises the proximal causes of the behaviour and 
circumstances" (p. 86) [29], which severs as the best method for studying the groundwater commons in Lijiang. The summary of the methodology is presented as follows. All data cited in this paper are from the Statistical Communiqué of the Lijiang Municipality on the 2016 National Economic and Social Development unless indicated otherwise.

\begin{tabular}{|c|c|c|}
\hline Data Source & Scope & Purpose \\
\hline General background study & $\begin{array}{l}\text { Chinese water management } \\
\text { system study, Lijiang city water } \\
\text { management study, general } \\
\text { background study on the city of } \\
\text { Lijiang }\end{array}$ & $\begin{array}{l}\text { Study the general economic, } \\
\text { political and demographic } \\
\text { context of the City of Lijiang, as } \\
\text { well as the natural environment } \\
\text { of groundwater management }\end{array}$ \\
\hline Semi-structured interviews & $\begin{array}{l}30 \text { households' interviews were } \\
\text { carried out randomly } \\
\text { throughout the } \\
\text { neighbourhoods of the Old } \\
\text { Town district and surrounding } \\
\text { areas around the water sources }\end{array}$ & $\begin{array}{l}\text { Qualitative analysis of factors } \\
\text { that may have influenced } \\
\text { groundwater management } \\
\text { system and its institutional } \\
\text { arrangement in Lijiang, as well } \\
\text { as local communities' response } \\
\text { to groundwater change }\end{array}$ \\
\hline Key informant interviews & $\begin{array}{l}\text { In-depth interviews with local } \\
\text { officials from various } \\
\text { governmental bodies, } \\
\text { qualitative information } \\
\text { collected were about local } \\
\text { water management system, } \\
\text { histories, and trends. }\end{array}$ & $\begin{array}{l}\text { Analysis of the institutional } \\
\text { arrangement of groundwater } \\
\text { management in the region }\end{array}$ \\
\hline Archives study & $\begin{array}{l}\text { Official statistics, demographic } \\
\text { data, local archives on } \\
\text { groundwater, collection of } \\
\text { historical data on water } \\
\text { management in Lijiang }\end{array}$ & $\begin{array}{l}\text { Analysis of local water } \\
\text { management histories, general } \\
\text { timeline of groundwater } \\
\text { changes }\end{array}$ \\
\hline
\end{tabular}

Figure 2. Summary of case study.

The paper maps out the storyline and thorough evidence to illustrate this local-level groundwater overexploitation case study to depict the "tragedy of the Lijiang groundwater commons". The case of Lijiang is particularly interesting because it presents a contradictory scenario that matchless natural and cultural beauties being overexploited without careful planning and management. Water was regulated as an isolated natural resource in a world cultural heritage city, rather than the cultural essence of the city and community according to the shamanic belief of local ethnic tribe of Naxi. Seeing into the groundwater commons is an important attempt because it allows us to better understand cases like Lijiang with rich natural resources and cultural traditions getting lost in the process of mass tourism development.

This paper employs a case study approach combined with institutional analysis under an integrated social-ecological framework. It takes two stages to analyse the case study. First, the paper analysed the fragility of Lijiang groundwater. This provides a general picture of Lijiang's groundwater overexploitation scenario. Secondly, the paper goes on to analyse groundwater as the commons under its institutionalised governance process in Lijiang, in the following order: identify the SES systems key variables; analyse interactions among these key variables; identify the outcomes of their interactions; compare the case with design principles of adaptive management.

\section{The Case of Lijiang}

\subsection{Natural Environment}

Lijiang is located in the northwest of Yunnan province in China, as shown in the map in Figure 3. It has a total area of more than $20,500 \mathrm{~km}^{2}$, with jurisdiction over Old Town County, Yulong Naxi 
Autonomous County, Yongsheng County, Huaping County, and Ninglang Yi Autonomous County. Lijiang municipality has a total population of about 1.28 million, among which almost half are farmers (2016 data) [30]. The GDP of Lijiang is still below the national average and provincial average. Three major water systems are covering two drainage areas throughout Lijiang municipality. The Jinsha River and Yalong River are both major tributaries of the Yangtze River, which involves 98\% of Lijiang's drainage area. Only 1.9\% locates within the Lancang River drainage area, see the map adapted from [31].

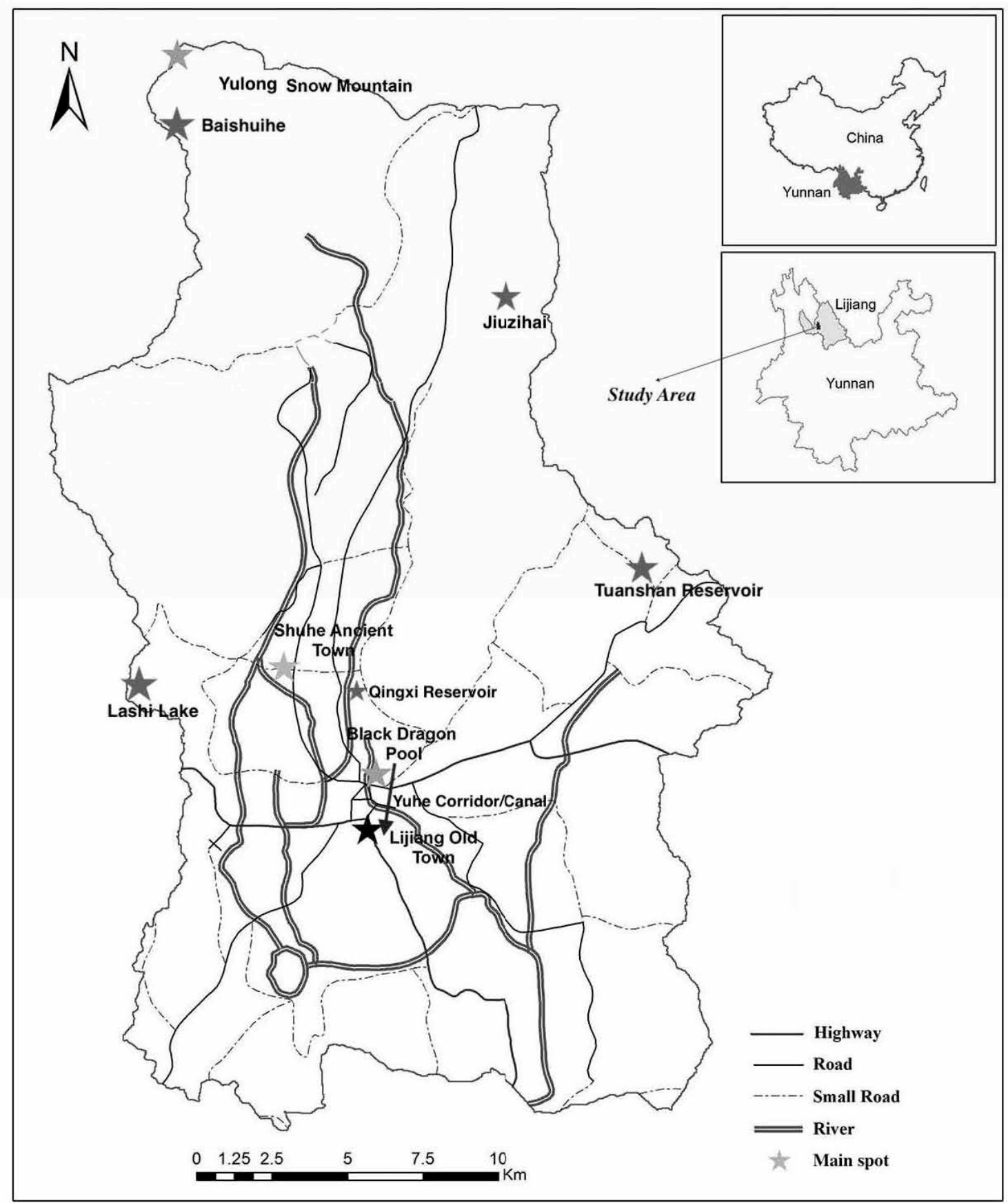

Figure 3. Map of the study site.

The general trend of terrain goes high from the northwest and low to the southeast, sloping from the northwestern plateau to the south of Yunnan and the eastern edge of the Hengduan mountain ranges. Therefore, the elevation rises sharply from $1015 \mathrm{~m}$ in Huaping to $5596 \mathrm{~m}$ on Yulong Snow 
Mountain within less than $200 \mathrm{~km}$. 94\% of Lijiang's total area is mountain, leaving only around 6\% of flatland in the basin and valley. The very limited flatland in the basin became the most populated area in Lijiang. Lijiang basin has the largest population density of 1195 person $/ \mathrm{km}^{2}$. Lijiang basin, being the entire municipality's political, economic and cultural centre, also suffered from the most serious water shortage and pollution in the region.

The forest coverage rate in Lijiang is $40.3 \%$, benefited from conservation as a key area of the national natural forest protection project. The plants belong to two vegetation belts, namely subtropical evergreen broad-leaved forest belts and cold temperate zone coniferous forest belts in the eastern Qinghai-Tibet Plateau. Rich plant resources provide a good habitat for animals. However, the historical deforestation since the 1950s in plateaus such as the Jinsha River valley, Yulong snow mountain and Jiuzi basin, has led to a sharp decline of natural forest in the region, ecological degradation, which then led to the dissolution of the Yulong glaciers, and decline of groundwater level in the basin. Deforestation in water source areas further exacerbated desertification and soil erosion in Lijiang basin and surrounding areas.

\subsection{Social, Economic and Cultural Features of a World Heritage Site}

Lijiang basin, with a total area of $180 \mathrm{~km}^{2}$ is the main focus of this paper. Lijiang basin has an altitude of $2400 \mathrm{~m}$, surrounded with mountains. The flourishing forests in surrounding mountains and a group of glaciers in the Yulong snow mountain to the northwest maintained river streams and springs flowing throughout the basin (As estimated, Yulong snow mountain glaciers obtain about 1.1 billion $\mathrm{m}^{3}$ water resources in ice form). The natural and manmade waterways constructed a network of canals and channels to water the Old Town of Lijiang. The UNESCO World Heritage site Old Town of Lijiang was the ancient centre for the Naxi people. It was designated as a world heritage site for the following Outstanding Universal Values, defined by the UNESCO World Heritage Centre in Figure 4.

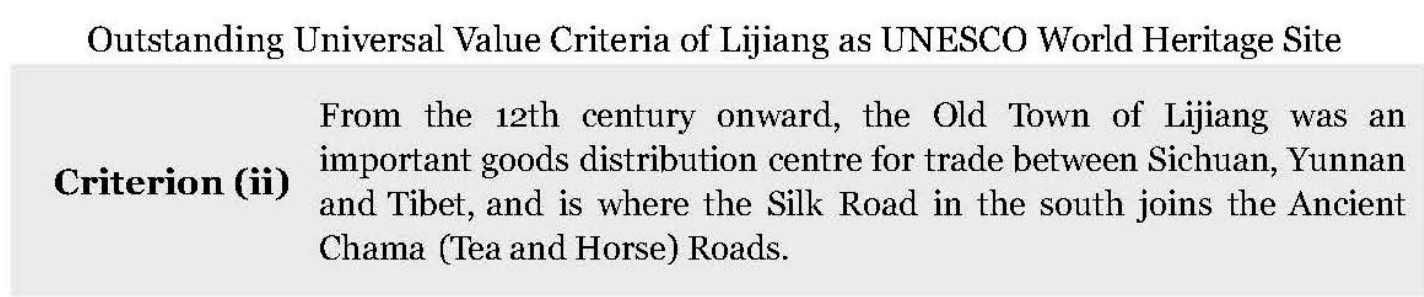

The three parts of the Old Town of Lijiang: Dayan Old Town (including the Heilong Pool), Baisha housing cluster and Shuhe housing cluster, Criterion (iv) fully reflect the social, economic and cultural features of the different periods, following the natural topography of mountains and water sources to form an outstanding settlement combining the residential traditions of Naxi, Han, Bai and Tibetan people.

The Old Town of Lijiang has integrated the mountains, rivers, trees and

Criterion (v) architecture to create a human habitat featuring the unity between man and nature.

Figure 4. Outstanding universal Values of the UNESCO World Heritage site Old Town of Lijiang (from UNESCO World Heritage Centre website).

The mysterious and beautiful valley of Shangri-La described by James Hilton in Lost Horizon is Lijiang. Yulong snow mountain is the holy mountain for the local residents, the Naxi people. The earliest record of human habitation in the region could be dated back to the 7th century. This tranquil wonderland is covered with matchless natural beauty and exotic cultures. However, being isolated in 
the mountains and trapped in low-level of social-economic development, Lijiang was far beyond its fictitious meaning of paradise.

Inscription to the UNESCO World Heritage List in 1997 dramatically changed Lijiang's fate. Tourism has been developed to its maximum capacity at the highest speed in recent years. In 2016, Lijiang hosted 35.2 million visitors in total, which generated total revenue of 60.8 billion Yuan. Lijiang municipality has an urbanization rate of $37.4 \%$ (2016 data). The local residents and visiting tourists have exceeded Lijiang's environmental carrying capacity, which would have a negative impact on groundwater.

\subsection{Water Resource in Lijiang}

In general, water resource is in abundance in Lijiang, with an average total reserve of multiple years of 8 billion $\mathrm{m}^{3}$. The average water resource per capita in Lijiang was around $4 \mathrm{~m}^{3}$, above the provincial level in Yunnan and the national average. However, the water resource has a very uneven geographical distribution in Lijiang. The political and economic centre of Lijiang basin, where the most populated, has the lowest water resource per capita of $1200 \mathrm{~m}^{3}$ per capita, only about $1 / 5$ of the municipal average. Lijiang basin has an average rainfall of $970 \mathrm{~mm}$ over the years. The total estimated groundwater reserve in Lijiang basin is 0.18 billion $\mathrm{m}^{3}$.

The rainfall in Lijiang is unevenly distributed throughout the year. The rain season between May to October takes up to $80-90 \%$ rainfall of the year, while the dry season between November to April only accounts for $10-20 \%$ of total rainfall.

Most of Lijiang's groundwater reservoirs are mainly recharged by surrounding major springs and atmospheric precipitation, supported by melting water of snow-capped glaciers. The total supply is $5838 \mathrm{~L} / \mathrm{s}$. The melting water of ice and snow accounts for $13 \%$ of total recharge supply, surrounding large springs accounts for $54 \%$, while the atmospheric precipitation infiltration recharges for $29 \%$. Lijiang has an annual mean rainfall of $1018.4 \mathrm{~mm}$. The average groundwater reserve of multiple years calculated by Lijiang government was about 2.8 billion $\mathrm{m}^{3}$. The pore phreatic water in loose rock mass takes up to $3 \%$ of total municipality's groundwater reserve; the karstic water in carbonate rocks mostly locates in the west of Lijiang, taking over $37 \%$ of total groundwater reserve; the fissure water in bedrocks takes up $60 \%$ of the total reserve, spreading in the eastern areas.

The centralized drinking water source protection areas in downtown Lijiang include Qingxi Reservoir, Tuanshan Reservoir, Sanshu River, and Black Dragon Pool (in Old Town District) as a backup water source. Tourism and leisure activities in those areas have been banned recently due to the severe water shortage in Lijiang. Rural domestic wastes and wastewater are not properly processed. Overusing fertiliser also leads to big pressure on the environment.

The groundwater supply has dramatically decreased over recent years with $30-45 \%$ average annual reduction. In 2012, groundwater supply reduced by $44 \%$ compared to the previous year, supplied only 18.5 million $\mathrm{m}^{3}$ groundwater, $81 \%$ from the shallow aquifer and $19 \%$ from deep aquifer. Further worsened by boosting tourism and urbanization, water scarcity and pollution became alarming in Lijiang.

\section{Results}

\subsection{Fragility of Lijiang's Groundwater Commons}

The existing fragile conditions of the Lijiang groundwater were addressed in this section, which offered a general picture of the story before investigating its dynamic governance process.

According to the 2012 public data of Lijiang water resources, there was 18.49 million $\mathrm{m}^{3}$ groundwater supply over the year, reduced by $44 \%$ compared with the previous year. Among all groundwater supply, there were $81 \%$ coming from shallow aquifers, only $19 \%$ coming from deep aquifers. Sharply increased water use by household and production sectors largely encroached upon water use for ecological preservation and environmental maintenance. 
Groundwater is of great importance to Lijiang, especially the basin where the Old Town locates. Densely populated Lijiang basin faces a large water demand. The demand has increased considerably because of the huge number of tourists coming in each year. The total shallow aquifer groundwater reserve of Lijiang municipality was 2.7 billion $\mathrm{m}^{3}$. The basin obtained about 1 billion $\mathrm{m}^{3}$ (2011 data).

The groundwater in Lijiang is mainly exploited in two ways. Most populated regions like the Lijiang basin drill wells. Areas close to springs would use drainages to build concentrated water sources for the region. By 2010, there were 8700 wells extracting groundwater in Lijiang. However, it is believed that the actual number is much larger because many private hostels and restaurants, even car wash facilities in and around Old Town of Lijiang have been illegally drilling wells.

There is a group of water springs in the Black Dragon Pool (helongtan, a pond of 40,000 $\mathrm{m}^{2}$, hereafter as BDP) supplying water continuously to the Old Town of Lijiang, which has also become a famous scenic spot. BDP locates in the northeast of Lijiang basin. Besides the natural middle stream flowing from Black Dragon Pool to the Old Town, two other man-made streams were flowing from BDP to the Old Town respectively in the east and west, built since the Yuan Dynasty to the Qing Dynasty. The spring water is supplied from the Jiuzihai recharge basin, which is also a dissolution zone. The groundwater recharging area in Jiuzihai is around $168 \mathrm{~km}^{2}$. When the annual rainfall goes above $1400 \mathrm{~mm}$ in Jiuzihai, the water supply for BDP spring discharge is sufficient. BDP springs are mostly abundant in October in normal years, with a maximum recorded annual runoff of $3.75 \mathrm{~m}^{3} / \mathrm{s}$. BDP supplies water to about 10,000 people living in the Beimen community, averagely it supplies $14,000 \mathrm{~m}^{3} / \mathrm{d}$ in normal years.

Another much bigger spring group locate several miles away from BDP-Qingxi Reservoir. It can supply over 22 million $\mathrm{m}^{3}$ water each year, covering over 100,000 people in Lijiang basin. The total reservoir capacity is $1.03 \mathrm{~m}^{3}$, it supplies water to local residents and also recharges water supplies to BDP and Old Town. Qingxi reservoir is located $2.5 \mathrm{~km}$ to the north of Lijiang Old Town, in the Qingxi village. It is believed to have a much more stable groundwater supply from the Yulong snow mountain and glaciers. The causal relation between Qingxi groundwater recharge and rainfall is not as evident as BDP. Qingxi reservoir has never completely dried up, which makes it an essential backup for BDP and Old Town water supply. Qingxi springs have an average total outflow runoff of 25.2 million $\mathrm{m}^{3}$, with the maximum runoff of $1.6 \mathrm{~m}^{3} / \mathrm{s}$ and minimum runoff of $0.35 \mathrm{~m}^{3} / \mathrm{s}$.

Over the years' drought and over-extraction of groundwater in the region, the capacity of those three reservoirs have all been severely influenced, the BDP has already stopped supplying water. The Sanshuhe reservoir has a designed minimum runoff of $56,000 \mathrm{~m}^{3}$ per day, but the actual supply reduced to around $30,000 \mathrm{~m}^{3}$; the Qingxi reservoir has a designed minimum runoff of $60,000 \mathrm{~m}^{3}$ per day, but the actual supply reduced to about $24,000 \mathrm{~m}^{3}$; the Tuanshan reservoir has a designed minimum runoff of $10,000 \mathrm{~m}^{3}$ per day, but it could barely reach this level. Averagely, Lijiang basin requires about $68,000 \mathrm{~m}^{3}$ to $73,000 \mathrm{~m}^{3}$ water per day, but the actual water supply with all reservoirs combined could only reach $60,000 \mathrm{~m}^{3}$. To solve the problem, the Lijiang water supply company started transferring water from other regions, like Baishuihe, to ease the crisis.

BDP is one of the main groundwater sources to supply the urban areas in the Lijiang basin. It provides about $180,000 \mathrm{~m}^{3}$ water each year, supplying water directly to more than 3000 local residents. The elevation of spring group capacity of BDP is $2420 \mathrm{~m}$, gathering water in the beautiful BDP park several hundred meters away from the Elephant Mountain foot. On the other hand, BDP maintains the waterways flowing throughout the Old Town, with an average runoff of 14 million $\mathrm{m}^{3}$ in normal years. The Old Town would be a "dead" city if the water dries up in all canals and channels. So, in a sense, BDP is the water reserve to maintain this heritage site and its local residents, as well as the overwhelming tourists. Ironically, the beautiful sceneries and rich cultures attract more tourists to the city, bringing unprecedented huge pressure to the groundwater conservation in BDP. The tourism boost generated striking growth of hotels, restaurants and other tourism-related service industries. Both the size and speed of growth are beyond expectation and immediately became out of control. A large number of illegal wells were drilled in the region, rapidly overexploited the BDP groundwater 
reserve. Eventually, a record-long dry up occurred in 2012. BDP springs dried up completely from 21 January 2012, after 956 days, a tiny stream of water came from the springs on 5 September 2014. Very limited spring water did not last long. Only 134 days later, BDP springs were completely dried up again. Old Town of Lijiang, consequently, dried up as well. Lijiang government had to transfer water from Lashi Lake and Baishuihe Lake several miles away. BDP dry up incident also caused other environmental issues. Yuhe canal used to connect water flows from BDP to the Old Town. When BDP pond dried up the Yuhe canal also dried up and caused severe pollution in the canal.

There were recorded histories of spring dry-up in BDP since Qing Dynasty around 1736AC. It occurred about once every 20 years from the late 18th century to early 19th century. Entering the 20th century, the spring dry-up speeded up to once every 5 years. Entering the 21st century, the spring dried up every year. In recent years, the springs in BDP have constantly dried up, along with increasingly dry-up frequency and duration. Lijiang suffered from severe drought since 2009. However, the longest dry-up record of 965 days occurred after a great boost of tourism in the region. Tourism, especially mass tourism, obviously has had a serious impact on Lijiang's water quality and environment. On the other way around, severe water shortage and environmental degradation have already put great pressure on tourism development. The Lijiang government initiated a Black Dragon Pool Spring Conservation Project, aiming to protect the spring water system in BDP. The project built four groundwater observation wells around the pond, and another three groundwater observation wells in Luogoucun, Baimalongtan, and Xianghelicheng throughout the Lijiang basin. This is to build a dynamic monitoring system on underground water flows of the springs in BDP.

Qingxi Pond also rapidly reduced its water runoff when the BDP was completely arid. Aside Lijiang municipal water supply company extracting water from Qingxi reservoir, there are others extracting water from it too. They are Old Town middle school, municipal vocational school of ethic tribes, Heibaishui forest administration bureau and Senlong spring water company.

The water quality for those two groundwater sources has also degraded over the years. The major pollutant to the water is nitrate in Qingxi Pond, and bacteria in BDP. Mang rural water supply sources are contaminated by bacteria, the rate of unsafe drinking water in the rural area across Lijiang reached $79 \%$.

Another worrying fact is that, not only touristic regions in Lijiang basin experienced a dramatic loss of groundwater, but also the residential areas in the basin were monitored in a quite critical situation. Many families also illegally drilled wells in their backyards or gardens. Lijiang municipal water resource administration office investigated the entire basin, identified four large over-exploited groundwater reserves with a total area of $25.5 \mathrm{~km}^{2}$. Some regions extracted so much groundwater that the water level decreased over $20 \mathrm{~m}$ in wells. Yet, the actual over-extracted groundwater volume still has not been identified, because of the lack of monitoring wells and measures in those regions.

Over-capacity extraction of groundwater and further drilling to deeper aquifers forced the geological formation of Lijiang basin changed dramatically. Decades of over-extraction of groundwater has already caused underground subsidence sinking in the region, known as "regional groundwater depression cone". Such sinking modified the original hydrology and forced groundwater moving toward a vertical direction. Vertical movement of groundwater provides preferential conditions for the rainfalls to be absorbed to the underground but also makes it easier to disseminate pollutants from the surface to underground.

In the past, dynamic monitoring of groundwater reserve was almost absent. The entire municipality had only one well for monitoring, and not built for groundwater, but for monitoring earthquake. The well had a depth of $310 \mathrm{~m}$, monitoring aquifers in depths of $167-310 \mathrm{~m}$. The monitoring well was built in the Old Town of Lijiang, where the most serious extraction of groundwater happened. From 1999 to 2007, the originally water-abundant area rapidly dropped its groundwater level for more than $16 \mathrm{~m}$. In the year of 2007, two hotels (Heibaishui Hotel and Senlong Hotel) alone extracted over $200 \mathrm{~m}^{3}$ groundwater per day. In 2012, Lijiang water resource administration built four groundwater monitoring wells in and around the BDP. 
The water demand has been rising fast over the years, worsened by the drought, the water supply in Lijiang is critical. Almost all regions in Lijiang municipality need water supply transferred from far-away reservoirs. From January to June each year, the water supply would decrease because of rainfall shortage. On the other hand, that period of time is the peak season for agricultural irrigation, hence water supply always becomes tight. Tourism boost in Lijiang also radically boosted real estate in the region, partially residential and partially hospitality. The fast speed of urbanization to nearby areas further stressed water supply capacity.

\subsection{Institutionalised Governance Process}

\subsubsection{Identify the SES Systems Key Institution Variables}

The main institutional variables must be identified first, to examine the Lijiang groundwater case under the SES system. From the perspective of social-ecological systems integration, Lijiang groundwater management is a complex system involving multiple stakeholders, such as resource ecology, local farmers, tourism businesses, government agencies, and NGOs. To further analyse the interaction between variables in SES systems and their outcomes, it is necessary to combine the specific research scales and research objects to indicate the basic status of these variables in the systems [32]. In Lijiang's case, the focus of research scale is primarily local with some reference to the national water governance structure, while the research objects identified as key variables for analysis in this section are institutional structures of groundwater management.

The urban water use in Lijiang basin is managed by the construction department, while the other water use is managed by the water resource administration. There are many different departments involved in the management of water resources, some deal with water source but not water supply, while others manage water supply regardless of drainage and water pollution. Overlapping administration on water resource with unclear responsibilities makes it extremely difficult to conduct scientific planning and effective management. Did not form an authoritative, unified, integrated water resources management system. Lijiang basin is under the jurisdiction of two different local authorities-Old Town District and Yulong Naxi Autonomous County, which made it even more difficult for the management of water resources. Water sources and recharging zones are mainly located in Yulong County, while the water users are concentrated in Old Town. A large amount of irrigation water supply in Yulong County has to compromise for urban water supply in Old Town. The conflicts are getting more prominent.

Accompanied by the continuous expansion of urban construction in scale and thriving development of service industry based on tourism, the problems of monitoring and management of water resources in Lijiang have become increasingly prominent. The monitoring coverage of water resources, especially groundwater is low, and the frequency of monitoring projects does not meet the requirements. The monitoring and analysis capabilities of groundwater and water ecology are relatively weak. The available water monitoring information has a very low level of digitalization, hence difficult to be shared with other stakeholders. Therefore, Lijiang's overall water resource management and monitoring capabilities need to be further improved.

The regulatory capacity of water management is insufficient. As the main administrator of groundwater in Lijiang, the Lijiang water resource bureau has a water resource management office, but only one staff working in the office. There are water resource monitoring/management teams based in the respective county/district government. Old Town district government, for instance, has a team of 7 staffs working on Old Town area's water management and monitoring. Currently, the water management work in Lijiang still relies heavily on fiscal transfers from the national government and Yunnan provincial government, with very little support from local government. Few counties are willing to use water-use charge revenue to support management and monitoring expenses, but still very limited. 
The "three red lines" (hongxian) have been repeatedly emphasis over the years, namely, redline of water exploitation and use; water use efficiency control; and water use functional regions' pollution control. However, Lijiang's water management system has not fully built its resource protection and management mechanisms, such as assessment mechanism for emergency forecasting, monitoring technology and funding system.

\subsubsection{Analyse Interactions among These Key Variables under IAD General Framework}

The previous section identified key institutional variables in the Lijiang groundwater case, and the next step was to investigate the interactions between these key variables. Establishing as many interactions between variables as possible within social-ecological systems is critical to understanding its complexity. In social-ecological systems, variables interact at different temporal and spatial scales [33]. The variable interactions change along with the change of time and space and adapt through the feedback mechanisms until reaching the tipping points to substantial, abrupt and persistent regime shifts of the resource systems or its ecosystems [34,35]. The Institutional Analysis and Development (IAD) framework focuses on the action situation and analyses the interactions and their feedback between actors and action situation under various impacts of "external" factors such as biophysical conditions, attributes of community, and rules-in-use [36,37]. As in Figure 5, the IAD framework is an important analytical approach to understand interactions and feedbacks throughout SES systems $[16,38]$.

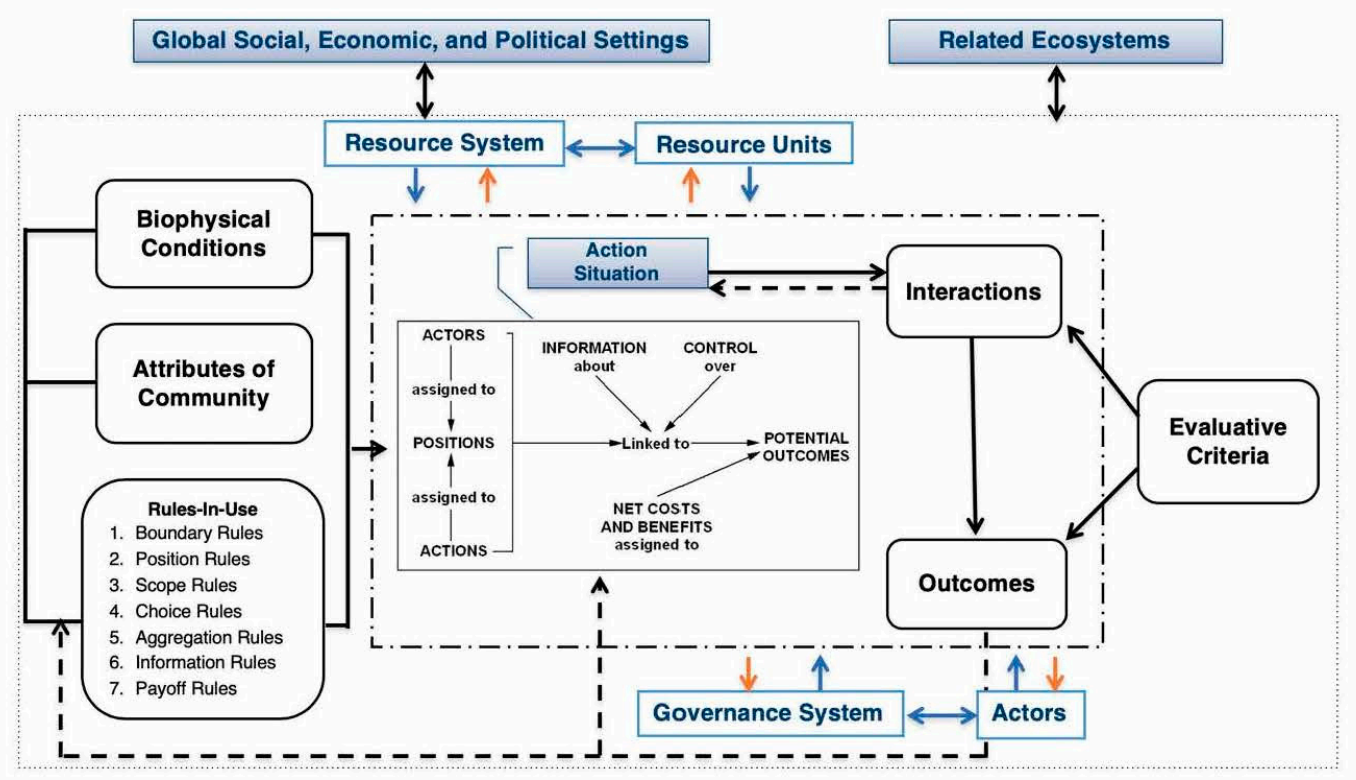

Figure 5. Institutional Analysis and Development (IAD) Framework. This adaptation of Ostrom's IAD framework is to include the wider tiers of backgrounds in which human behaviours are deeply embedded. Start with the micro operational level of action arena (in the centre), which is to map out diverse actors and a sophisticated action situation. Second step is to identify resulting patterns of interactions \& outcomes. The evaluation should be on both interactive process and the outcomes. This helps us to understand the evolving dynamics and possible institutional/policy alternatives. The next step is to draw out direct causal links \& feedbacks between the evolving dynamics and the resource system \& governance system over a longer period of time. Biophysical conditions, local attributes and rules in use are external factors, but they too have direct impacts on the action arena. While the interactive patterns would also have feedbacks towards those external factors, for instance, change the rules in use. Global settings \& interdependent ecosystems could also influence the entire process through underling divergent or convergent values. For instance, the profound neo-liberal logic of free market and privatisation. Adapted from Ostrom $(2005,2007)$ and Zhang $(2018)[20,21,27]$. 
Lijiang municipal government published "Lijiang municipal groundwater management regulation (No. 37 of Lizhengfa 2006)" in May 2006, under which a management centre at municipality-level was established. This centre aims to regulate water supply, water usage and drainage water processing, pollution control on water resources at a unified platform across the entire municipality. Under the 2006 regulation, some illegally extracted wells were closed up, some others were requested to apply for groundwater extraction licence, the extraction volume was also set with quota. Until August 2017, there were 17,718 wells extracting groundwater in Lijiang basin, recorded by the government. Among those wells, about $1 \%$ were deep-aquifer wells. After investigation, the local government closed up 324 wells, 114 wells among which were deep-aquifer wells. Those groundwater wells were recorded with details under different categories for the first time, such as residential, hotel, school, enterprises, etc. The local government aims to build a long-term mechanism for groundwater use. The aim is to assign all qualified groundwater users' water-use licences and dynamically monitor them in the unified system. It requested that one well must obtain one profile on record with all the details of this particular well. However, the local administration system still obtrudes this groundwater management system. Lijiang basin is under two administrative jurisdictions-Old Town District and Yulong Naxi Autonomous County. This brings conflicts on coordination among different departments. Secondly, water resource management bureau has long been marginalised in the government system. Their implementation capability is much weaker than the "strong members" like fiscal and finance departments. Therefore, this management system calls for joint punishment measures implemented by the water resource administration and other relevant departments altogether, for instance, businesses and commerce administration and urban planning administration. The water management system in Lijiang is illustrated in Figure 6.

In December 2009, Old Town District Government firstly initiated an emergency action plan to cope with the rapid environmental degradation and ecological hazard. BDP and Qingxi were both included in the emergency action plan as the most crucial groundwater sources in the region. By 2010, the district government even established an action team of groundwater conservation, composed of 18 local administrative agencies including environmental agency, construction and development authority, urban planning bureau, public sanitation bureau, development and reform committee, water supply facilities etc. Lijiang municipality also complied an emergency action plan in 2012, which included groundwater over-extraction risks.

The overlapping administration across different authorities does not only reflect in policymaking and implementation but also groundwater monitoring and information sharing. The groundwater quality and capacity are mainly monitored by three authorities, Lijiang municipal environmental monitoring station, Lijiang disease control centre and Yunnan provincial water resourced administration Lijiang branch. Because those three bureaus belong to different administrative jurisdiction, their monitoring to BDP and Qingxi groundwater resources are not coordinated and the results are not shared among each other. Lijiang water resource administration started monitoring water quality in BDP in 1993, but they only started monitoring in Qingxi reservoir in 2009.

\subsubsection{Identify the Outcomes of Interactions}

Interactions between key variables also generated corresponding feedback, resulting in different outcomes. The interactions and their feedback mechanisms between actor and action situation can lead to three categories of outcomes-social performance measures, ecological performance measures and externalities to other SES systems [20,21]. The identification of multiple outcomes of system interactions can help us exploring successful adaptive management methods. Successful management models can adapt to system changes at different time and space with the support of the feedback mechanisms, which then in turn can strengthen the system's adaptive capacity [39]. 

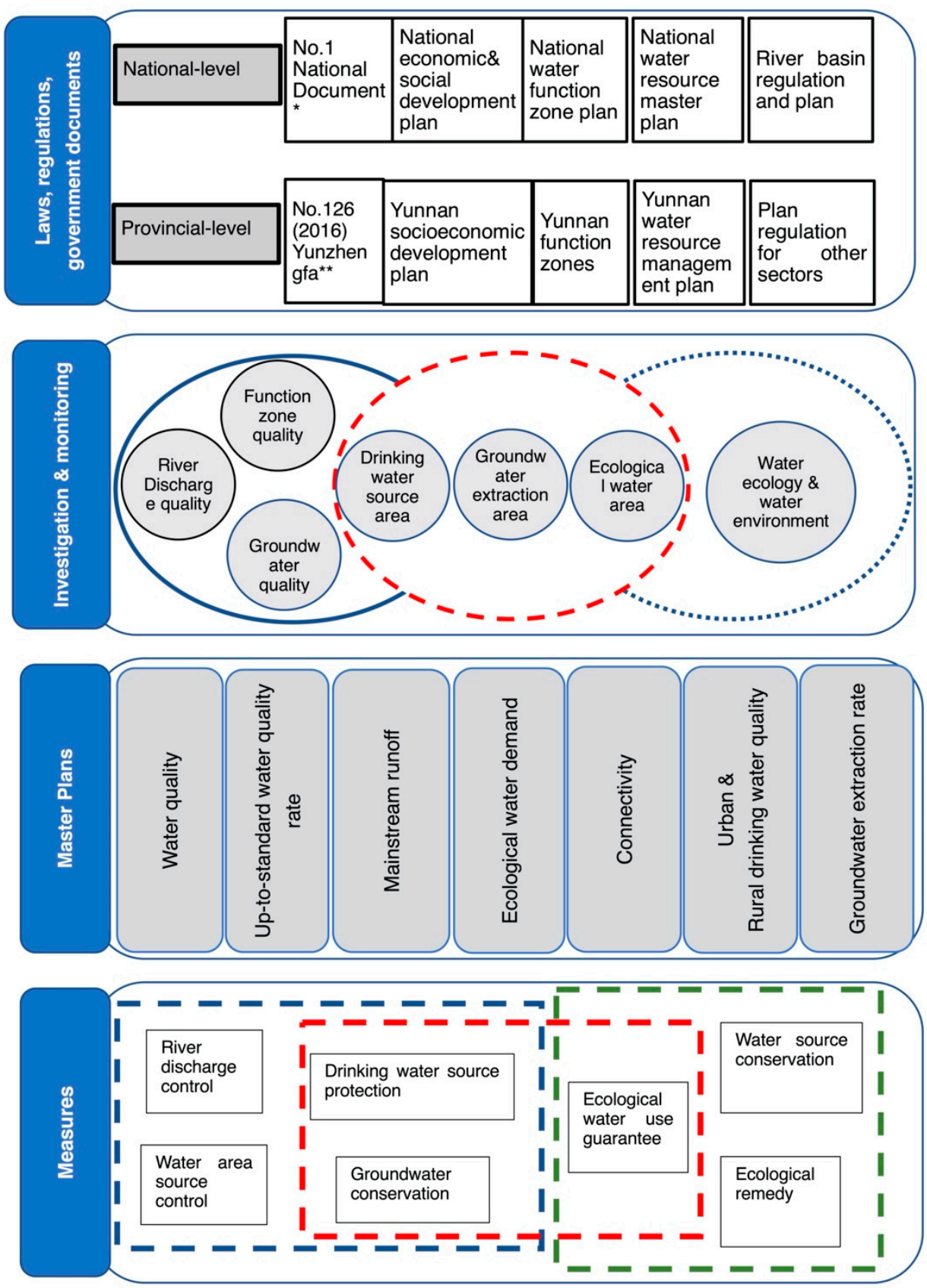

Figure 6. Lijiang water management system. ( ${ }^{*}$ No.1 National Document is an annual policy document issued by the State Council of PRC (People Republic of China), focusing on rural development; *No.126(2016)Yunzhengfa is Yunnan provincial policy document on Five-year-plan, 2016 for instance is No. 126 document.).

To solve the overlapping administration problem, Lijiang municipal government established a "river manager" (hezhang) system covering all the rilnteractions between key variables also provided corresponding feedback, resulting in different outcomes.Interactions between key variables also provided corresponding feedback, resulting in different outcomes.vers and lakes and canals in the city, and established a matching management mechanism for rivers, lakes, and reservoirs with clear responsibility, coordination, strict supervision, and strong protection. The party secretary of Lijiang municipality serves as the municipal "river manager", and the mayor serves as the deputy "river manager" at the municipal level. Other rivers and lakes canals are managed by rivers at all levels, including counties (districts), townships (towns, streets), and villages. By the end of 2017, Lijiang 
has established a system of four-level "river manager" system covering municipality/city, counties (districts), townships (towns, streets) and villages. Those "river managers" are responsible for the protection of the rivers, lakes and reservoirs. The goal is to maintain the water quality compliance rate of important rivers, lakes, and canals in water functional areas of $92 \%$ by 2020 .

The infrastructure facilities have been completed throughout the Lijiang basin. As early as 2013, the entire water supply system has covered the Lijiang basin. The DN100 pipelines are over $143 \mathrm{~km}$, connecting the Lijiang airport, Yulong Naxi Autonomous County to the south; connecting Shuhe ancient town to the north; connecting cultural industrial park to the east and Baihua villages in the west.

In 2010, Lijiang water resource administration applied specific funding of 3.1 million Yuan from the National Environmental Administration for water conservation in Lijiang, among which 0.8 million Yuan was used on BDP and Qingxi groundwater conservation.

There have been four major institutional changes after the groundwater crisis occurred. First is to set up the public hearing system for water resources management. There were 59 construction projects carried out public hearing between 2011-2015, the 12th Five-Year-Plan. Another five projects public hearing have been conducted since the 13th Five-Year-Plan. The second institutional change is the implementation of the water extraction permit system. Up to the end of 2017, there were totally 2060 Water Users Associations (WUAs) established, which registered and issued 49,302 sets of water extraction rights certificates. The third change is to implement the system of paying for the use of water resources. Lijiang's water resource fee levy has increased from 1.85 million Yuan in 2010 to 5.9 million Yuan in 2016 (excluding the Jinsha River cascade hydropower station water resource fees). The last institutional arrangement is to formalise the strict protection of groundwater resources. The organization was put in place to promote the construction of groundwater monitoring wells to dynamically record water level and water quality. The BDP groundwater monitoring wells are completed. The government set up strict enforcement of illegal extraction of groundwater resources, by means of investigation through communities, promotion of groundwater protection awareness, and joint legal enforcement on illegal extractions. Until the end of 2017, the total number of 37,000 promotion awareness materials have been distributed throughout the communities. The enforcement team thoroughly investigated and registered 17,718 groundwater wells, among which 356 groundwater wells have been sealed, including 135 deep wells and 221 shallow wells. Around $78 \%$ of deep aquifer groundwater wells have been closed up.

Faced with the increasingly severe water crisis in Lijiang basin, Lijiang started to promote the water-saving goal of "promoting the sustainable use of water resources, improving the water environment, and managing urban water-saving regulation" since 2012. According to the public government reports, 15 four-star/five-star hotels out of 17 in Lijiang have successfully established provincial-standard water-saving facilities by 2014. The coverage rates of water-saving facilitated enterprises and residential communities in Lijiang City have reached $26.55 \%$ and $18.82 \%$, respectively. InterContinental Lijiang Hefu Hotel, for instance, has established a well-functioning internal water recycling system, with a current daily processing capacity of $180 \mathrm{~m}^{3}$. Together with the collected rainwater, it can meet the needs of the hotel's landscaped circulation and vegetation water use. The actual water consumption of the hotel in 2014 was $76,000 \mathrm{~m}^{3}$, far below the average water consumption in the industry. However, the majority of illegal wells locates in a much smaller family-run guesthouse, hostels and inns, which are in a grey zone of administration. Almost all surrounding villages, beside Lijiang Old Town, started family guesthouses either by local villagers or rented to outside developers. Those small guesthouses extract groundwater illegally to reduce their operation cost. The size of the guesthouses may range from 10 rooms to 100 rooms, mostly occupied during peak season. Over recent years, the situation got worse and drilling shallow wells would not meet the demand of those guesthouses, also because the shallow aquifer groundwater is polluted with the uncontrolled discharge of sewage water and waste, many guesthouses chose to drill deep to extract clean groundwater. 
Since 2013, the administration centre of Lijiang municipal government has effectively saved water resources by adopting measures such as the construction of recycled water reuse projects and small-scale rainwater collection pools. The reclaimed water reuse system can produce $60 \mathrm{~m}^{3}$ of recycled water per day. There are 12 small rainwater collection pools saving nearly $1000 \mathrm{~m}^{3}$ water per year. In addition to other water-saving measures, the annual water consumption of the administrative centre has dropped to $37,000 \mathrm{~m}^{3}$, which is $15,000 \mathrm{~m}^{3}$ less than expected. Yet again, it is always easier to regulate registered buildings and houses for water recycling, such as the administration centre. It is much harder to regulate small businesses, especially the ones opened in villages. Car wash is a typical example. There are many villages located within the Lijiang basin, close to the world heritage site. The collectively-owned land in those villages cannot be trade privately. Therefore, many villages would use those land to build car wash businesses or restaurants. Those car wash shops extract large amount of groundwater for their daily use. This has been repeatedly reported to local government. However, local authorities, especially water resource administration have not solved this problem effectively.

Extended water pollution from surface water to groundwater is another big concern [40]. Lijiang built its very first sewage water treatment plant in 2000. Tourism boost started from the 1990s have discharged uncontrolled sewage water to rivers, canals throughout the Lijiang basin before 2000. Since 1997, Lijiang Old Town has initiated sewage treatment plants and sewage pipe network construction projects. The first sewage treatment plant was built by the end of 2000, with a daily processing capacity of 20,000 tons. There were $63 \mathrm{~km}$ network of sewage pipeline laid by December 2003, covering main streets, but still at a very low coverage rate of less than half throughout the Old Town. A large portion of sewage is still not included in the sewage pipeline. A large amount of sewage is discharged into the nearby water body, which intensified the water pollution.

\subsubsection{Compared with the Design Principles of Adaptive Management}

The comparison between the analysis of the Lijiang groundwater case and the design principles of effectively managed commons would allow us to better explore the main issues that may have contributed to this particular case. The long-enduring institutions of successfully-managed commons share certain similarities that are then abstracted into the so-called Design Principles [41,42], as summarised in Figure 7.

\begin{tabular}{|c|c|c|}
\hline & Ostrom (1990) & Cox et al. (2010) \\
\hline & & 1A: User boundaries: Clear boundaries between legitimate users and nonusers must be clearly defined. \\
\hline Principle 1 & Well-defined boundaries & $\begin{array}{l}\text { 1B: Resource boundaries: Clear boundaries are present that define a resource system and separate it from the larger } \\
\text { biophysical environment. }\end{array}$ \\
\hline & & $\begin{array}{l}\text { 2A: Congruence with local conditions: Appropriation and provision rules are congruent with local social and } \\
\text { environmental conditions. }\end{array}$ \\
\hline Principle 2 & $\begin{array}{l}\text { Congruence between } \\
\text { appropriatioun and } \\
\text { provision rules and local } \\
\text { conditions }\end{array}$ & $\begin{array}{l}\text { 2B: Appropriation and provision: The benetits obtained by users from a common-pool resource (CPR), as determined by } \\
\text { appropriation rules, are proportional to the amount of inputs required in the form of labor, material, or money, as determined } \\
\text { by provision rules. }\end{array}$ \\
\hline Principle 3 & $\begin{array}{l}\text { Collective-choice } \\
\text { arrangements }\end{array}$ & $\begin{array}{l}\text { Collective-choice arrangements: Most individuals affected by the operational rules can participate in modifying the } \\
\text { operational rules. }\end{array}$ \\
\hline & & 4A: Monitoring users: Monitors who are accountable to the users monitor the appropriation and provision levels of the users. \\
\hline Principle 4 & Monitoring & ${ }_{4} \mathrm{~B}$ : Monitoring the resource: Monitors who are accountable to the users monitor the condition of the resource. \\
\hline Principle 5 & Graduated sanctions & $\begin{array}{l}\text { Graduated sanctions: Appropriators who violate operational rules are likely to be assessed graduated sanctions (depending on } \\
\text { the seriousness and the context of the offense) by other appropriators, by officials accountable to the appropriators, or by } \\
\text { both. }\end{array}$ \\
\hline Principle 6 & $\begin{array}{l}\text { Conflict-resolution } \\
\text { mechanisms }\end{array}$ & $\begin{array}{l}\text { Conflict-resolution mechanisms: Appropriators and their officials have rapid access to low-cost local arenas to resolve } \\
\text { conflicts among appropriators or between appropriators and officials. }\end{array}$ \\
\hline Principle 7 & $\begin{array}{l}\text { Minimum recognition } \\
\text { of rights }\end{array}$ & $\begin{array}{l}\text { Minimal recognition of rights to organize: The rights of appropriators to devise their own institutions are not challenged } \\
\text { by external governmental authorities. }\end{array}$ \\
\hline Principle 8 & Nested enterprises & $\begin{array}{l}\text { Nested enterprises: Appropriation, provision, monitoring, enforcement, conflict resolution, and governance activities } \\
\text { are organized in multiple layers of nested enterprises. }\end{array}$ \\
\hline
\end{tabular}

Figure 7. Design Principles for long-enduring institutions of adaptive management for the commons, adapted from Ostrom (1990), Cox et al. (2010) [41,42]. 
A thorough investigation of groundwater reserve is crucial to prevent a similar tragedy of Lijiang. The basis of good management is a clear understanding of the resource. Lijiang had not investigated its groundwater capacity and condition before it was pushed into the overenthusiastic tourism development. As the result, both boundaries of users and resources were implicit, which caused a tremendous challenge to the recognition of rights in the groundwater management system.

Lijiang's groundwater management broke apart between administrative governance and local communities' participation. Collective-choice arrangements that traditionally embedded in Naxi culture in the local community was destroyed by mass tourism development, without supplying any alternative arrangements. The strong impulse of profit-seeking blinded people's eyes over their own precious resource, while the local authorities tried very hard to control with legal and administrative rules rather than reviving the local tradition and culture that respect the nature with great awe. Both parts of groundwater management are equally important, but bridging those two is even more important.

Lijiang basin, centred with the UNESCO world heritage site is the most famous tourist destination, which has brought tremendous wealth to local residents in a rather short period of time. On the other hand, the villagers living in nearby mountainous areas such as Jiuzihai basin are still trapped in a low level of economic and social development. However, their livelihood is essential to maintain the water source for the groundwater supply of Old Town. Therefore, there should have been a sustainable support scheme to transfer tourism benefits to those poor village communities and to encourage them to apply environmentally-friendly development approach in those water source areas, as described in principle 4 .

Although Lijiang basin consumes a large amount of water as the political and economic centre, agricultural water supply for irrigation is still the largest water consumer in Lijiang. Therefore, the conflict of water shortage between agricultural water use and other water use remains an essential problem. The conflict is particularly prominent between irrigation water demand in the Baisha township in the north of Lijiang basin and urban water supply of Lijiang city, as well as large Old Town landscape water demand. Especially during the dry seasons, the adjustment of Baisha irrigation water use could have an evident impact on urban water supply in the city. Therefore, measures such as adjusting agricultural structure and reasonable compensation for farmers if irrigation water has to be reduced may need to be considered to ease the conflicts.

On the other hand, regulating mass tourism in Lijiang will be the key to long-term sustainable development. Yulong snow mountain, for instance, is the foundation of groundwater reserve in the region. If the temperature increases by 1.6 degrees by 2050, the Yulong glacier area would shrink to about $22 \%$ of its current size. Given the fact that global warming has already affected its glacier, tourists should be restricted to help to conserve the glaciers. There is a golf course built very close to the glaciers at the elevation of $3100 \mathrm{~m}$ in Ganhaizi. Its maintenance requires a large amount of water use and chemical insecticides, which can be a threat to the snow mountain and its glaciers. Prohibiting touristic activities in BDP and Qingxi reservoir can be of great importance too. Water source contamination is also a big concern for Lijiang's groundwater conservation.

\section{Discussion}

\subsection{Water Management in China}

To understand the management of Lijiang groundwater, we need to consider the general institutional context of China's water management system.

China published the Water Law of the People's Republic of China in 1988, in which both surface water and groundwater are included. Since the 1980s, water resource management started to build into its current form throughout the whole of China. The Water Law was then revised in 2002, to further emphasise water conservation managed by different water-use functions. The water resource management institutional system in China is composed of laws, regulations of both professional 
ministries and regional governments, governmental action plans from different levels of government. The institutional system seems sufficient on paper, but far beyond enough coping with the urgent situation of water shortage, scarcity and pollution.

Secondly, even many ministries set up water laws and regulations, they did not build a coordinating mechanism among different ministries. For instance, there is Water Law, Water and Soil Maintenance Law issued by water resource ministry; there is Water Pollution Law issued by environmental protection ministry; others include agriculture, shipping, construction ministries. The whole process from extracting water, to water use, then to drainage and sewage water processing, etc. is not complete as it is supposed to be, because of multiple administrative jurisdictions. One example is Water Pollution Law, it states regulating departments and different jurisdiction boundaries among provinces, but it did not offer those coordinating agencies any legal enforcement capability, which makes this statement weak in practice.

As seen in Figure 8 that groundwater management is less elaborated compared to surface water management. This is partly because of the "invisibility" of groundwater, but also because of the shortcoming of the institutional system designed for water management several decades ago.

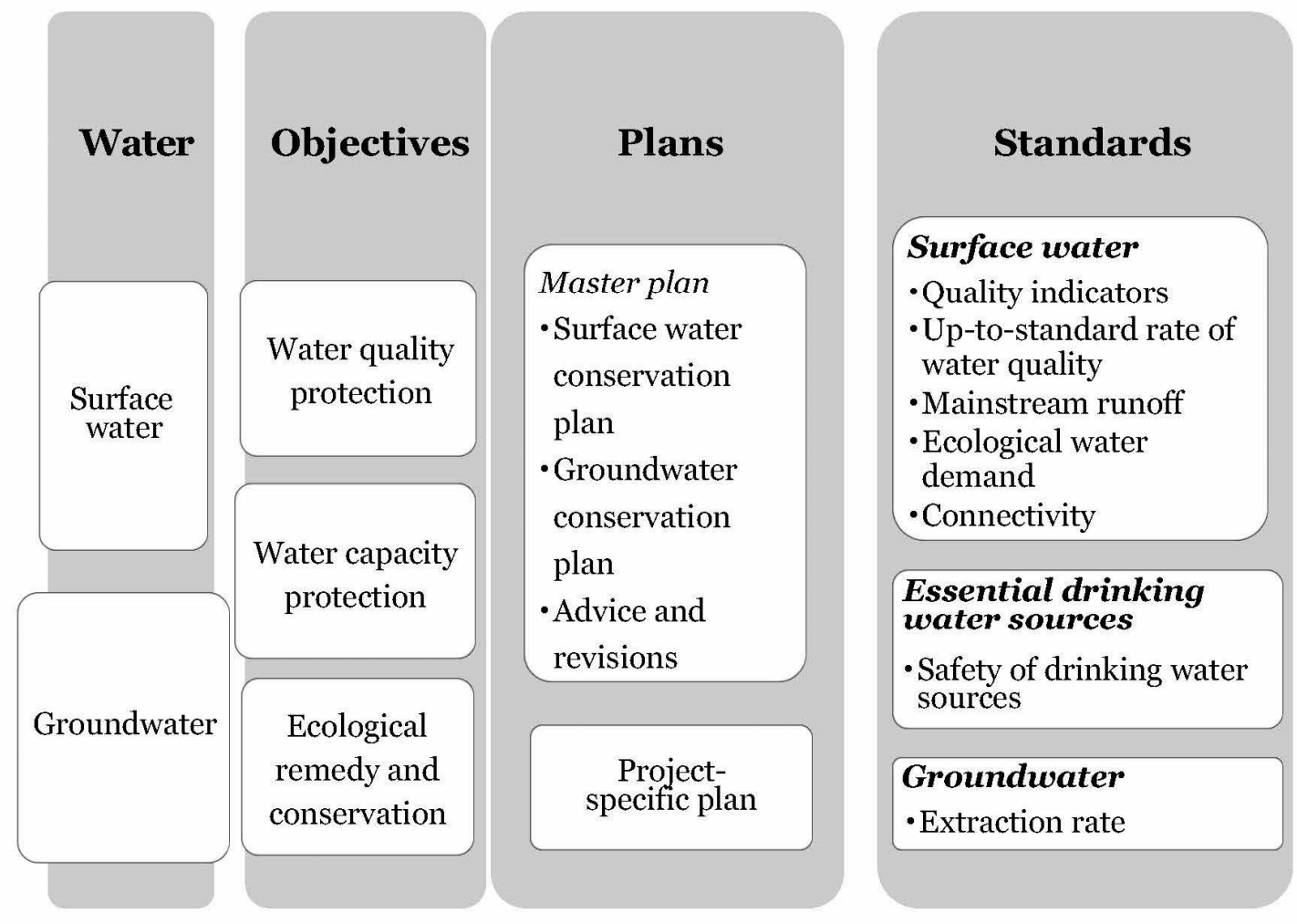

Figure 8. Water management system in China.

Water governance to solve water crisis is divided into macro-level water control and micro-level water management. Water management deals with a small inclusive system, in which a cost-benefit analysis can assess its efficiency. Water control involves much wider interests over time and space. A large-scale water control project requires the large-scale mobilization of capital, material and human resources. Water control also requires a far-sighted vision and comprehensive planning. Almost all water control projects are carried out by the central or local organs of the state.

Water control has to deal with water-saving, transfer and pollution treatment. So, it is better to integrate the whole river basin, including upstream and downstream underground and surface water and integrating the tributaries and the parent river in the same management system. Comprehensive water governance in river basins can link up flood-control systems, dams, water supply, irrigation, 
shipping, domestic water use and industrial water use, water-saving, wastewater drainage and treatment of pollution. It is essential to ensure that each link is separately managed but comprehensively governed to avoid conflicts with others.

Water control capability is determined by three key elements-finance, technology and institutional capacity. Larger financial resources and the use of advanced technology makes practice possible, but they are both constrained by the institutional framework [43]. A comprehensive plan for national water resources is necessary from the start. This plan must also fit in with a strategic socioeconomic plan. A medium-term plan is designed according to current and future economic, social and political development needs. For instance, water control is planned for different regions in the 12th FYP to address local conditions. The priority of the north is the treatment of water pollution. In the northeast, water supply is the priority to meet the strategic need to construct a national grain base and to revitalize old industrial bases. In the central area, flood control, rural water supply and transferring water to the north are keys. The water-abundant southwest is the reservoir for the entire country. The water-shortage northwest demands an entirely different development path from the southwest: water-efficient agriculture, upgrading industrial efficiency and speeding up economic transformation. Pollution control and ecological remediation of the key river basins are crucial. Thus, the plans are designed according to each region's different challenges and resource endowment. Although some problems seemed similar, their underlying causes are different. For instance, both central and western regions suffer from severe shortages of rural drinking water. However, the difficulty in the west is the shortage of facilities, while the central area suffered from severe water pollution. Therefore, although symptoms are similar, their treatment must differ. Long-term strategic plans like the South-North Water Diversion (SNWD) are implemented via medium plans such as the FYP.

Although various financing channels are explored, government fiscal support remains the backbone of water control projects. However, a state-oriented approach has shortcomings: the water management system and policy framework may be incomplete; the comprehensive management of whole river basin could be weak, and there might be insufficient overall planning for all water resources. Particularly, unplanned exploitation of water and an approach always prioritizing construction over management are difficult to change.

The government was, however, determined to change this. The 12th FYP (2011-2015) set people-oriented development as the priority in water management, to build a water-saving society, transforming an unsustainable economic development model, and making use of technological innovation. More frequent and deeper participation of society in water management required more cohesive management and coordination of diverse stakeholders. However, reform cannot proceed beyond the pace of socio-economic transitions. For instance, water rights pricing and financing systems have been developed, but they still rely heavily on the current market and financial institutions for operation.

As long as a framework for water control has been built, the water management systems dealing with concrete problems at a micro-level are easier to coordinate. Only if water control and water management are integrated can water governance be sustainable. As Nickum concludes, China is trying to find the "right balance between the public and private good characteristics of water" within a "continuous dialectic between state-directed and market-directed approaches", using a unified strategy that in based on "planning with due consideration for all concerned" and the "fragmented authoritarianism" of the state offers effective institutional and policy frameworks of "responsibility systems" of the "world's largest bureaucracy" for water governance [44].

\subsection{A World Cultural Heritage with Outstanding Universal Values}

In a way, the case of Lijiang differed from that of the other Chinese cities. It is a World Cultural Heritage city with outstanding universal cultural and natural values. Groundwater is the lifeline of these values and heritages. 
Lijiang Old Town has been designated as UNESCO world cultural heritage. Although heritage sites might appear similar to common-pool resources such as public grazing ground and fishing stock, they are also inherently different from typical common pool resources [45,46]. The differences are big enough to render the results from common-pool resource theory less applicable to heritage sites. The main difference between a heritage site and a typical common-pool resource is that even when over-usage is prevented, the heritage would still deteriorate, and the speed of deterioration depends on the amount of investment made to maintain and preserve the site [47]. Hence, the solution suggested by the common-pool theory can only deal with the over usage problem, but cannot ensure the optimal amount of investment to maintain and preserve the site.

Secondly, cultural heritage helps us to define who we are, building up our cultural identity with both old and new values and interests, by shaping the way we see ourselves and the way others interpret us. The concept of Outstanding Universal Value (OUV) is the core of UNESCO cultural heritage definition. It is defined as "cultural and/or natural significance which is so exceptional as to transcend national boundaries and to be of common importance for present and future generations of all humanity" (UNESCO).

OUV is the current world cultural heritage valuation standard and value-based management approach, which listed six criteria to judge the general value of heritage. For instance, a world heritage with OUV has "to exhibit an important interchange of human values, over some time or within a cultural area of the world", or it has "to be directly or tangibly associated with events or living traditions, with ideas, or with beliefs, with artistic and literary works of outstanding universal significance" (UNESCO World Heritage Centre). With that cultural heritage being consumed via sightseeing, it is the cultural identity or OUV that is conveyed towards consumers/visitors through an informational process. So, the primary goal of designating global heritage is to maintain and convey its OUV, which has been totally ignored in Lijiang's case. Our society is built with cultural spaces with community values and traditions [48], in Lijiang's case, those were preserved in Naxi culture. Naxi culture values and respects nature with great awe, which should have been regarded as our common human heritage.

What unites the integrated commons, from natural resources of groundwater to Naxi culture to social cohesive development, is their legal and moral ownership by the Lijiang people [49]. The commons comprise not just marketable assets, but social institutions and cultural traditions that help define our commons. The local social infrastructure of cultural institutions, rules, traditions and trust are absent from the governance of groundwater in Lijiang. The Old Town of Lijiang has survived several hundred years with a great history of reciprocal history of the shared commitment of Naxi and other ethnic tribes. Therefore, the failure of groundwater commons is only a part of a much larger tragedy of lost common culture and belief. Streams and canals that flow throughout Old Town are well preserved over the history by moral and social norms, such as the guidance of Shu god (shamanic god of nature in Naxi culture) - "the invisible hand of community" [50]. Respecting nature, preserving water, cherishing rivers and worshipping snow mountains are a set of common moral presumptions and expectations for managing daily life in old Lijiang.

\subsection{What Caused Lijiang's Groundwater Crisis?}

Lijiang's groundwater management, operating under China's water management system and as a holy place with exceptional cultural and natural values for humanity, posed both typical groundwater exploitation problems and unique features of its governance shortcomings.

Overall, the Lijiang groundwater crisis was caused both by natural reasons and human overexploitation. Climate change had an obvious impact on Lijiang's fragile groundwater system. The annual temperature in Lijiang between 1979-2016 showed an upward trend, the temperature fluctuations in the 1980s and 1990s were relatively small. Compared with the 1990s, the annual average temperature in 2000-2010 and 2010-2016 increased respectively by $0.48^{\circ} \mathrm{C}$ and $0.95^{\circ} \mathrm{C}$, indicating that the temperature rises more significantly since the 21 st century [51]. The annual precipitation in Lijiang 
also showed a decreasing trend. The impacts of temperature and precipitation on groundwater can be significant.

Although the causal relationship between rainfall and groundwater recharge volume has been difficult to match in a strictly linear relationship, rainfall's obvious impact on groundwater recharge is an important cause not to be ignored. The sharp drop of rainfall over recent years contributed largely to the groundwater shortage in Lijiang. The BDP main recharge area-Jiuzihai's rainfall has dramatically decreased over the years. As the southernmost snow mountain in the northern hemisphere, Yulong snow mountain and its glaciers have suffered from global climate change and also mass tourism development. The glaciers have visibly retreated over recent years. Water shortage would be dramatically escalated if glacier water reserves disappear.

On the other hand, human activities and exploitation also had a tremendous impact on groundwater. Vegetation is a crucial element to maintain groundwater reserve. Over-exploitation on Jiuzihai grassland via grazing livestock and construction of new buildings has caused soil erosion, which then led to the weak recharging capability of Jiuzihai to BDP. Between the 1950s to 1980s, the forest in Lijiang was lodged at a shocking speed, the entire forestry coverage reduced almost half in three decades. Since the 1990s, the national forest conservation project stopped lodging and tried to restore forests in the region. However, Jiuzihai basin has long suffered from stony desertification with serious soil erosion. This has caused sand blockages within its groundwater system.

The ecosystem in Lijiang is generally fragile as it located in high altitude mountainous areas. The farmland fertility is low in the region, also because of the remoteness, the regional economic and social development is comparably lower than the regional average. Therefore, Lijiang's development must balance between strong motivations of economic growth and fragile eco-environment.

Another cause is mismanagement of groundwater by local authorities, largely overwhelmed by unexpected tourism boost since the 1990s. The high-speed increase of urban water demand has taken up irrigation water supply over the years. There are unavoidable conflicts among urban water demand, irrigation demand and landscape water demand for tourism, not just for present times, but also in the future. Although water use licensing system has been built to control groundwater extraction, the illegal well drilling and groundwater extraction are still in a grey zone that requires further attention.

Rapid urbanization sharply increased the water demand in Lijiang. Before known worldwide as the UNESCO world heritage site, Lijiang municipality only had about 0.87 million residents in 1978 . The population fast grew to around 1.27 million in 2015. Water demand in Lijiang basin has increased from 3 million $\mathrm{m}^{3}$ in 1985 to almost 10 million $\mathrm{m}^{3}$ in 2010. To cope with the large demand of increasing population in the basin and a large number of tourists visiting Lijiang each year, a substantial part of irrigation water has been transferred to the city to supply its water use, such as from Sanshuhe reservoir (originally designed just for irrigation water supply). The agricultural water supply has decreased by approximately $30 \%$ from the 1980 s to 2000 s, because of the huge water demand of the city. During those three decades, urbanization eroded about $42 \%$ of farmland.

Based upon a preliminary study of Lijiang basin's groundwater quality, $41 \%$ of the groundwater quality was good, $35.5 \%$ were poor, and $17.5 \%$ were extremely poor [52]. The main factor influencing groundwater quality is ammonia nitrogen. The major source of ammonia nitrogen pollution is urban residents' domestic garbage and domestic sewage water, as well as agricultural fertilizers, pesticides and sewage irrigation used on a large scale. The following major pollutant in Lijiang groundwater is acidic sewage.

Inappropriate treatment of household wastes also threatened groundwater quality due to the large size of the visiting population and local residents. On one hand, a large amount of domestic waste, with the support of bacteria, would continuously decompose protein to produce amino acids. The amino acids continue to be divided and infiltrated into groundwater. On the other hand, fertilizers and pesticides are widely used in vegetable planting. Only a part of the nitrogen in chemical fertilizers and pesticides is absorbed by plants, most of them remain in the soil, seeping with water, making 
nitrogen content in groundwater increase. At all monitoring sites, the faecal coliforms in groundwater exceeded beyond the normal standard, which just confirms this inference-bacteria survive in a large number of nutrients.

The SES framework serves as a valuable instrument to facilitate the design of policies and institutions. The policy is a deliberate course of action adopted by a set of stakeholders. Policies are formulated during the institutionalised governance process, in which the agendas are fixed by official documents and activities are efficiently implemented on the ground. The SES framework defines the commons broadly, well beyond its natural resource boundaries. Its analytical framework of IAD captures key variables of the dynamic governing process and the interactions and feedback between these variables, as well as their outcomes, to analyse the problem. The framework then delivers contributions to adaptive management in line with its effective design principles.

\section{Concluding Remarks}

It has been a long-term challenge for social scientists to diagnose complex interactions and feedbacks of social-ecological systems. The SES framework proposed by Ostrom is a significant step forward in this direction. This paper embraced SES framework to provide a systematic interpretation of Lijiang's groundwater overexploitation, showing the applicability of the SES framework in diagnosing the complexity of social-ecological systems, especially from an institutional perspective [53]. Given the large number of variables and their complex interactions in social-ecological systems, traditional empirical analysis is already difficult to fulfil the task of identifying key variables, not to mention establishing a systematic understanding of the causal link between these variables. From this perspective, the SES framework represents a new generation of research on the commons studies that provides a general analytical framework and systematic identification of variables [54]. This paper presented an example of applying this methodology, although it is still relatively crude, it offered further exploration in the area that lacks systematic studies-groundwater governance research. Looking to the future, transforming our world for a sustainable future is a challenge and it requires us to explore ways to integrate systemic SES thinking into everyday decision-making.

There were two significant findings in the case of Lijiang. First, institutional arrangements play an important part in resource management, but their analysis is lacking between macro modelling of planetary boundaries of Earth and micro surveys of individual and community behaviour [55-57]. A helpful instrument for filling this gap can be the SES framework. It offers a general framework to identify the key variables and their interactions, and it links theoretical studies of the commons to the practical use of adaptive management. Second, Lijiang's designation of Outstanding Universal Values as heritage sites ironically harmed its local cultural intimacy [58], which for generations nurtured collective action in Naxi community, triggering the tragedy of its groundwater commons. The integration of cultural, natural and economic values has to be interrogated-what value does it really matter? It also urges us to scrutinise the "value-based" management approach when its foundational value judgements are either incomplete or misleading.

The Lijiang groundwater case proves that groundwater management can be characterised as the integrated commons within the SES framework, where groundwater is not an isolated natural resource, and its management is a dynamic institutionalised process. In the case of Lijiang, its unique cultural and natural values are inseparable from the point of view of groundwater governance. Nesting inside China's overall water management system, Lijiang groundwater case also posed some typical issues of governance shortcomings of such a system. It sheds some light on future studies addressing complex relationships between social and ecological processes, contributing to future institutional and policy design.

Funding: This research was funded by the British Academy project [PF170136].

Acknowledgments: The author would like to express her deepest appreciation to Peter Nolan (University of Cambridge) and Benzhi Shi (Yunnan University) for their invaluable comments and suggestions made over the years. 
Conflicts of Interest: The author declares no conflict of interest. The founding sponsors had no role in the design of the study; in the collection, analyses, or interpretation of data; in the writing of the manuscript, and in the decision to publish the results.

\section{References}

1. Guilfoos, T.; Pape, A.D.; Khanna, N.; Salvage, K. Groundwater management: The effect of water flows on welfare gains. Ecol. Econ. 2013, 95, 31-40. [CrossRef]

2. Ranjan, P.; Kazama, S.; Sawamoto, M. Effects of climate change on coastal fresh groundwater resources. Glob. Environ. Chang. 2006, 16, 388-399. [CrossRef]

3. Fan, Y. Groundwater in the earth's critical zone: Relevance to large-scale patterns and processes. Water Resour. Res. 2015, 51, 3052-3069. [CrossRef]

4. Benson, A.K. Applications of ground penetrating radar in assessing some geological hazards: Examples of groundwater contamination, faults, cavities. J. Appl. Geophys. 1995, 33, 177-193. [CrossRef]

5. Gorelick, S.M.; Zheng, C. Global change and the groundwater management challenge. Water Resour. Res. 2015, 51, 3031-3051. [CrossRef]

6. Theesfeld, I. Institutional challenges for national groundwater governance: Policies and issues. Ground Water 2010, 48, 131-142. [CrossRef]

7. López-Corona, O.; Padilla, P.; Escolero, O.; Armas, F.; García-Arrazola, R.; Esparza, R. Playing with models and optimization to overcome the tragedy of the commons in groundwater. Complexity 2013, 19, 9-21. [CrossRef]

8. Meinzen-Dick, R.; Janssen, M.A.; Kandikuppa, S.; Chaturvedi, R.; Rao, K.; Theis, S. Playing games to save water: Collective action games for groundwater management in andhra pradesh, india. World Dev. 2018, 107, 40-53. [CrossRef]

9. Rudestam, K.; Langridge, R.; Brown, A. "The commons" as a dynamic variable in understanding strategic alliances of scale: A groundwater case study in pajaro valley, california. Environ. Sci. Policy 2015, 52, 33-40. [CrossRef]

10. Cody, K.C.; Smith, S.M.; Cox, M.; Andersson, K. Emergence of collective action in a groundwater commons: Irrigators in the san luis valley of colorado. Soc. Nat. Resour. 2015, 28, 405-422. [CrossRef]

11. Seward, P.; Xu, Y. The case for making more use of the ostrom design principles in groundwater governance research: A south african perspective. Hydrogeol. J. 2018, 27, 1017-1030. [CrossRef]

12. Hardin, G. The tragedy of the commons. Science 1968, 162, 1243-1248.

13. Bromley, D.W.; Feeny, D. Making the Commons Work: Theory, Practice, and Policy; ICS Press: San Francisco, CA, USA, 1992.

14. Ostrom, E. Beyond markets and states: Polycentric governance of complex economic systems. Am. Econ. Rev. 2010, 100, 641-672. [CrossRef]

15. Feeny, D.; Berkes, F.; McCay, B.J.; Acheson, J.M. The tragedy of the commons: Twenty-two years later. Hum. Ecol. 1990, 18, 1-19. [CrossRef] [PubMed]

16. Araral, E. Ostrom, hardin and the commons: A critical appreciation and a revisionist view. Environ. Sci. Policy 2014, 36, 11-23. [CrossRef]

17. Cox, M.; Villamayor-Tomas, S.; Arnold, G. Design principles in commons science: A response to "ostrom, hardin and the commons" (araral). Environ. Sci. Policy 2016, 61, 238-242. [CrossRef]

18. Dietz, T.; Ostrom, E.; Stern, P.C. The struggle to govern the commons. Science 2003, 302, 1907-1912. [CrossRef]

19. Poteete, A.R.; Janssen, M.; Ostrom, E. Working Together: Collective Action, the Commons, and Multiple Methods in Practice; Princeton University Press: Princeton, NJ, USA, 2010.

20. Ostrom, E. A diagnostic approach for going beyond panaceas. Proc. Natl. Acad. Sci. USA 2007, 104, 15181-15187. [CrossRef]

21. Ostrom, E. A general framework for analyzing sustainability of social-ecological systems. Science 2009, 325, 419-422. [CrossRef]

22. Folke, C. Resilience: The emergence of a perspective for social-ecological systems analyses. Glob. Environ. Chang. 2006, 16, 253-267. [CrossRef]

23. Mumby, P.J.; Chollett, I.; Bozec, Y.-M.; Wolff, N.H. Ecological resilience, robustness and vulnerability: How do these concepts benefit ecosystem management? Curr. Opin. Environ. Sustain. 2014, 7, 22-27. [CrossRef] 
24. Turner, B.L.; Matson, P.A.; McCarthy, J.J.; Corell, R.W.; Christensen, L.; Eckley, N.; Hovelsrud-Broda, G.K.; Kasperson, J.X.; Kasperson, R.E.; Luers, A. Illustrating the coupled human-environment system for vulnerability analysis: Three case studies. Proc. Natl. Acad. Sci. USA 2003, 100, 8080-8085. [CrossRef]

25. Turner Ii, B.L. Vulnerability and resilience: Coalescing or paralleling approaches for sustainability science? Glob. Environ. Chang. 2010, 20, 570-576. [CrossRef]

26. McGinnis, M.D.; Ostrom, E. Social-ecological system framework: Initial changes and continuing challenges. Ecol. Soc. 2014, 19, 30. [CrossRef]

27. Zhang, Y. Crossing the divide: An integrated framework of the commons. Evol. Inst. Econ. Rev. 2018, 15, 25-48. [CrossRef]

28. Bromley, D.B. Academic contributions to psychological counselling. 1. A philosophy of science for the study of individual cases. Couns. Psychol. Q. 2007, 3, 299-307. [CrossRef]

29. Bromley, D.B. Academic contributions to psychological counselling. 2. Discourse analysis and the formulation of case-reports. Couns. Psychol. Q. 1991, 4, 75-89. [CrossRef]

30. Lijiang Municipal Statistics Bureau. Statistical Communiqué of the Lijiang Municipality on the 2016 National Economic and Social Development; Bureau, L.M.S., Ed.; Lijiang Municipal Statistics Bureau: Lijiang, China, 2017.

31. Su, Y.; Hammond, J.; Villamor, G.B.; Grumbine, R.E.; Xu, J.; Hyde, K.; Pagella, T.; Sujakhu, N.M.; Ma, X. Tourism leads to wealth but increased vulnerability: A double-edged sword in Lijiang, South-West China. Water Int. 2016, 41, 682-697. [CrossRef]

32. Agrawal, A. Common resources and institutional sustainability, in The Drama of the Commons; National Academies Press: Washington, DC, USA, 2002; pp. 41-85.

33. Ostrom, E. Do institutions for collective action evolve? J. Bioeconom. 2014, 16, 3-30. [CrossRef]

34. Reyers, B.; Folke, C.; Moore, M.L.; Biggs, R.; Galaz, V. Social-ecological systems insights for navigating the dynamics of the anthropocene. Annu. Rev. Environ. Resour. 2018, 43, 267-289. [CrossRef]

35. Castilla-Rho, J.C.; Rojas, R.; Andersen, M.S.; Holley, C.; Mariethoz, G. Social tipping points in global groundwater management. Nat. Hum. Behav. 2017, 1, 640-649. [CrossRef]

36. Ostrom, E. Understanding Institutional Diversity; Princeton University Press: Princeton, NJ, USA, 2005; pp. 393-432.

37. McGinnis, M.D. An introduction to iad and the language of the ostrom workshop: A simple guide to a complex framework for the analysis of institutions and their development. Policy Stud. J. 2011, 39, 169-183. [CrossRef]

38. Boettke, P.J.; Aligica, P.D. Challenging Institutional Analysis and Development: The Bloomington School; Routledge: London, UK, 2009.

39. Shinn, J.E. Adaptive environmental governance of changing social-ecological systems: Empirical insights from the okavango delta, botswana. Glob. Environ. Chang. 2016, 40, 50-59. [CrossRef]

40. Baoying, N.; Yuanqing, H. Tourism development and water pollution: Case study in lijiang ancient town. China Popul. Resour. Environ. 2007, 17, 123-127. [CrossRef]

41. Ostrom, E. Governing the Commons. the Evolution of Institutions for Collective Action; Cambridge Univ. Press: Cambridge, UK, 1990.

42. Cox, M.; Arnold, G.; Tomás, S.V. A review of design principles for community-based natural resource management. Ecol. Soc. 2010, 15. [CrossRef]

43. Wang, Y. An Explaination of the Water Rights; Shanghai People's Publishing House: Shanghai, China, 2005.

44. Nickum, J. Water policy reform in china's fragmented hydraulic state: Focus on self-funded/managed irrigation and drainage districts. Water Altern. 2010, 3, 537.

45. McCay, B.J.; Acheson, J.M. The Question of the Commons: The Culture and Ecology of Communal Resources; University of Arizona Press: Tucson, AZ, USA, 1990.

46. Hess, C. Mapping the New Commons. In Proceedings of the Twelfth Biennial Conference of the International Association for the Study of the Commons, University of Gloucestershire, Cheltenham, England, UK, 14-18 July 2008.

47. Zhang, Y. Heritage as cultural commons: Towards an institutional approach of self-governance. In Cultural Commons: A New Perspective on the Production and Evolution of Cultures; Bertacchini, E.E., Bravo, G., Marrelll, M., Santagata, W., Eds.; Edward Elgar Publishing: Cheltenham, UK, 2012.

48. Brondizio, E.S.; Ostrom, E.; Young, O.R. Connectivity and the governance of multilevel social-ecological systems: The role of social capital. Annu. Rev. Environ. Resour. 2009, 34, 253-278. [CrossRef] 
49. De Stefano, L.; Lopez-Gunn, E. Unauthorized groundwater use: Institutional, social and ethical considerations. Water Policy 2012, 14, 147-160. [CrossRef]

50. Lejano, R.P.; Fernandez de Castro, F. Norm, network, and commons: The invisible hand of community. Environ. Sci. Policy 2014, 36, 73-85. [CrossRef]

51. Fang, J.; Pu, T.; Shi, X.; Wang, S.; Niu, H. Runoff variation and its influence factors in the yangong river basin of mt. Yulong region due to climate change. J. Glaciol. Geocryol. 2019, 41, 268-274.

52. Chen, M. Lijiang Basin Water Resource and Groundwater Quality Study; Kunming University of Science and Technology: Kunming, China, 2007.

53. Anderies, J.; Janssen, M.; Ostrom, E. A framework to analyze the robustness of social-ecological systems from an institutional perspective. Ecol. Soc. 2004, 9, 18. Available online: http://www.ecologyandsociety.org/ vol9/iss1/art18/ (accessed on 7 November 2020). [CrossRef]

54. Agrawal, A. Studying the commons, governing common-pool resource outcomes: Some concluding thoughts. Environ. Sci. Policy 2014, 36, 86-91. [CrossRef]

55. Rockström, J.; Steffen, W.; Noone, K.; Persson, Å.; Chapin, F.S.; Lambin, E.F.; Lenton, T.M.; Scheffer, M.; Folke, C.; Schellnhuber, H.J. A safe operating space for humanity. Nature 2009, 461, 472-475. [CrossRef] [PubMed]

56. Bai, X.; van der Leeuw, S.; O’Brien, K.; Berkhout, F.; Biermann, F.; Brondizio, E.S.; Cudennec, C.; Dearing, J.; Duraiappah, A.; Glaser, M.; et al. Plausible and desirable futures in the anthropocene: A new research agenda. Glob. Environ. Chang. 2016, 39, 351-362. [CrossRef]

57. Emel, J.; Roberts, R. Institutional form and its effect on environmental change: The case of groundwater in the southern high plains. Ann. Assoc. Am. Geogr. 1995, 85, 664-683. [CrossRef]

58. Herzfeld, M. Cultural Intimacy: Social Poetics in the Nation-State; Routledge: New York, NY, USA, 2005.

Publisher's Note: MDPI stays neutral with regard to jurisdictional claims in published maps and institutional affiliations. 